ISSN: 2091-0304 (print)

DOI: https://doi.org/10.3126/jncs.v42i1.35360

\title{
Utilization of Charred Water Hyacinth (Jalkumvi) as Biosorbent for Removal of Ca(II) Ion from Aqueous Solution
}

\author{
Arun Bhujel', Krishna Wagle ${ }^{1}$, Bishow Regmi', Bibek Sapkota ${ }^{1}$, Bhoj Raj Poudel ${ }^{1}$, \\ Surendra K. Gautam*1 \\ ${ }^{1}$ Department of Chemistry, Tri-Chandra Multiple Campus, Tribhuvan University, Kathmandu, Nepal \\ *Corresponding E-mail: sgautam2055@yahoo.com \\ (Received: September 3, 2020; Revised: December 19, 2020; \& Accepted: January 10, 2021)
}

\begin{abstract}
A promising adsorbent, charred water hyacinth $(\mathrm{CWH})$ for the removal of $\mathrm{Ca}(\mathrm{II})$ from the aqueous solution was explored by heat treatment of water hyacinth followed by chemical activation with acidified zinc chloride $\left(\mathrm{ZnCl}_{2}\right)$. The adsorbent was characterized using scanning electron microscopy (SEM) and electron dispersive $\mathrm{X}$-ray (EDX) spectroscopy. Batch adsorption techniques were conducted for $\mathrm{Ca}(\mathrm{II})$ adsorption to assess the adsorption isotherm, effect of $\mathrm{pH}$, contact time, initial $\mathrm{Ca}$ (II) concentration, adsorbent doses, and adsorption kinetics. The SEM micrograph illustrates the rough and irregular surface morphology and EDX spectra confirm the successful adsorption of $\mathrm{Ca}(\mathrm{II})$ on the adsorbent surface. The equilibrium adsorption data better fitted to the Freundlich isotherm model having a maximum adsorption capacity $\left(\mathrm{q}_{\max }\right)$ of $319.75 \mathrm{mg} / \mathrm{g}$. The highest percentage of adsorption was found at $\mathrm{pH}$ 1.5. The adsorption of $\mathrm{Ca}(\mathrm{II})$ by $\mathrm{CWH}$ decreased at the higher metal concentration and lower adsorbent doses. The adsorption of $\mathrm{Ca}(\mathrm{II})$ ions onto $\mathrm{CWH}$ followed the pseudosecond-order kinetics model. Overall, these results suggested that the as-prepared CWH can be used as an ecofriendly, economical and efficient alternative for the removal of $\mathrm{Ca}(\mathrm{II})$ from the aqueous solution.
\end{abstract}

Keywords: Charred water hyacinth, Freundlich adsorption isotherm, pseudo-second-order kinetics, SEM, EDX

\section{Introduction}

Calcium, considered as an important determinant of water hardness and a $\mathrm{pH}$ stabilizer, is abundant due to its natural occurrence in Earth crust in the form of limestone, marble, calcite, dolomite, gypsum, fluorite, and apatite and occurs as $\mathrm{Ca}(\mathrm{OH})^{+}(\mathrm{aq}), \mathrm{Ca}(\mathrm{OH})_{2}$ (aq) or as $\mathrm{CaSO}_{4}$ in seawater [1]. Calcium is also abundant in the human body present it amount of $1.2 \mathrm{~kg}$ may be found as calcium phosphate supporting substance causing bone and tooth growth along with vitamin D [2]. Recently, increasing concerns have been raised regarding the increased amount of calcium in drinking water which causes the increment in the hardness of water [3]. Some recent studies have revealed that the excessive intake of calcium might increase the risks of cardiovascular diseases [4], growth reduction and reproductive failure [5], the buildup of lime-scale that fouls plumbing and promotes galvanic corrosion [6], influence metabolism, and affects kidney performance [7].

Calcium can be removed by ion-exchange [8], nanofiltration [9], ultrafiltration and reverse osmosis [10] processes which are economically expensive and are

(c) Nepal Chemical Society incomplete methods. Regarding these shortcomings, adsorption is considered to be an efficient and environmentally friendly method. Adsorption is the surface phenomena that occurs when a gas or liquid solute accumulates on the surface of a solid or a liquid (adsorbent), forming a molecular or atomic film (adsorbate) [11,12].

Activated carbon is the most popular adsorbents for the removal of metal ions due to its highly developed porosity, large internal surface area, and relatively high mechanical strength. Its adsorbing potential is affected by the surface charge, type of surface functional groups, specific surface area, and pore size distribution [13]. The powdered activated charcoal can be obtained efficiently from various agricultural waste materials like coconut husk, peat moss, wool, rice husk, exhausted coffee, etc. which is a potential adsorbent for adsorption separation of calcium [14]. The low-cost adsorbents with improved sorption capacities derived from agricultural wastes for the removal of metallic and non-metallic pollutants have been the center of study for researchers [15-17].

In this case, we study the adsorption capacity of 
$\mathrm{Ca}(\mathrm{II})$ on water hyacinth, a free-floating perennial aquatic plant of family Pontederiaceae, commonly known as Jalkumvi in Nepali, extracted from Begnash Lake, Kaski. The common water hyacinth (Eichhornia crassipes) is a noxious weed that has attracted worldwide attention due to its fast spread and congested growth, which lead to serious problems in navigation, irrigation, and power generation $[18,19]$. In Begnash Lake, water hyacinth is extracted during the growing season. The extracted raw materials are thrown as waste at the corner of the lake.

The conventional techniques used for the removal of $\mathrm{Ca}$ (II) from water are expensive for developing countries like Nepal. There are voluminous research works available in the literature regarding the use of waste biomass as an adsorbent for the removal of heavy metals [19,20], chromium [12,14,21,22], arsenic [23-25], phosphate [15,26], and $\mathrm{Ca}(\mathrm{II})[3,6,7]$ from aqueous medium. To the best of our knowledge, water hyacinth is a novel material and not studied yet for the removal of $\mathrm{Ca}$ (II) from water. Because of such circumstances, $\mathrm{CWH}$ is supposed to be a novel material herein studied and its application for removal of $\mathrm{Ca}$ (II) was proposed.

The objective of the present study was to prepare charred water hyacinth $(\mathrm{CWH})$ by heat treatment of water hyacinth at $400^{\circ} \mathrm{C}$ followed by chemical activation with acidified $0.1 \quad \mathrm{M} \mathrm{ZnCl}_{2}$ and to investigate its adsorption behaviors of $\mathrm{Ca}$ (II) from aqueous solution under different conditions through batch experiments. The adsorbent was characterized by SEM and EDX. The adsorption isotherm, effect of $\mathrm{pH}$, contact time, adsorbent doses, adsorption kinetics on $\mathrm{Ca}$ (II) adsorption were also studied and discussed.

\section{Materials and Method}

\section{Chemicals and analysis}

The adsorbent used for this study is the leaves of the water hyacinth. The water hyacinth was collected from the Begnas Lake of the Kaski district. Analytical grade chemicals were used without additional purification. All the solutions in the work were prepared by using deionized water. EDTA $\left(\mathrm{C}_{10} \mathrm{H}_{16} \mathrm{~N}_{2} \mathrm{O}_{8}, 99 \%\right.$ assay), hydrated magnesium chloride $\left(\mathrm{MgCl}_{2} .6 \mathrm{H}_{2} \mathrm{O}, 97 \%\right.$ assay $)$, calcium carbonate $\left(\mathrm{CaCO}_{3}, 98.5 \%\right.$ assay $)$, ammonium chloride $\left(\mathrm{NH}_{4} \mathrm{Cl}\right)$ were brought from local suppliers, manufactured from Thermo Fischer Scientific India Pvt. Ltd. (India). A standard stock solution of $\mathrm{Ca}$ (II) (1000 $\mathrm{mg} / \mathrm{L})$ was prepared by dissolving an exact amount of $\mathrm{CaCO}_{3}$ in deionized water. $\mathrm{Ca}$ (II) concentration in the test solution before and after adsorption was analyzed spectrophotometrically using ELICO SL 177 spectrophotometer.

\section{Preparation of adsorbent}

Thus collected raw water hyacinth was washed with tap water followed by distilled water and dried in sunlight for about 2-3 days. The carbonization was then conducted in a muffle furnace at $400^{\circ} \mathrm{C}$ for 3 $h$ in air. After carbonization, the residual char was grounded using a laboratory jar mill to pass between 25-50 mesh sizes.

Charred water hyacinth (CWH) was chemically activated with the help of acidified $0.1 \mathrm{M} \mathrm{ZnCl}_{2}$ at laboratory temperature. The grounded char was mixed with $\mathrm{ZnCl}_{2}$ solution of 1:2 ratio in porcelain. The sample was then activated in a muffle furnace at $600^{\circ} \mathrm{C}$ for $3 \mathrm{~h}$ for complete reaction. The mixture was washed with $1 \% \mathrm{HCl}$ and soaked in a hot water for $5 \mathrm{~min}$ and then dried at $120^{\circ} \mathrm{C}$ for $6-8 \mathrm{~h}$ in an oven. Finally, heat-treatment followed by chemical activation of raw water hyacinth gave activated biochar of water hyacinth [18]. Due to this chemical activation, the surface area of the adsorbent is expected to be increased which increases the adsorption sites $[27,28]$.

\section{Determination of $\lambda_{\text {max }}$ and calibration curve}

A Ca(II) ion solution of $25 \mathrm{ppm}$ concentration was prepared for the determination of $\lambda_{\text {max }}$ and calibration curve. For this $0.0,1.0,2.0,3.0,4.0,5.0,6.0$, and 7.0 $\mathrm{mL}$ of working $\mathrm{Ca}(\mathrm{II})$ solution of $20 \mathrm{mg} / \mathrm{mL}$ were taken in a different $25 \mathrm{~mL}$ volumetric flask and was acidified with $1 \mathrm{~mL}$ of $5 \mathrm{~N} \mathrm{H}_{2} \mathrm{SO}_{4}$ in each volumetric flask and shaken well. In each volumetric flask, 1.0 $\mathrm{mL}$ of $0.001 \mathrm{M}$ EDTA solution was added and shaken well. The remaining portion of the volumetric flask was filled with the distilled water. The absorption spectra of pinkish-blue colored calcium with EDTA complex was recorded with the help of a spectrophotometer (ELICO SL 177) against reagent blank solution. Thus, obtained adsorption data was plotted to find the calibration curve and absorption spectra for the determination of $\mathrm{Ca}$ (II) ions after the formation of a complex with EDTA at $\lambda_{\max } 520 \mathrm{~nm}$ [12].

\section{Batch adsorption studies}

The working solutions of required concentrations of $\mathrm{Ca}$ (II) ion were prepared to dilute the stock solution. The $\mathrm{pH}$ of the solution was adjusted by using acidified $0.1 \mathrm{M} \mathrm{ZnCl}_{2}$ and $2 \mathrm{~N} \mathrm{NaOH}$ solutions. $25 \mathrm{~mL}$ of the known initial concentration of $\mathrm{Ca}(\mathrm{II})$ was taken in a 
$125 \mathrm{~mL}$ reagent bottle and predetermined about $15 \mathrm{mg}$ of charred water hyacinth was added. The mixture in the reagent bottle was shaken for $24 \mathrm{~h}$ in a mechanical shaker at room temperature. The equilibrium was established. Thus obtained equilibrated solution was filtered with the help of filter paper and filtrate was used to analyze the remaining concentration of the metal ions, concentration before and after adsorption was determined by spectrophotometer at $\lambda_{\max }$ of 520 $\mathrm{nm}$ [29].

\section{Batch pH studies}

Batch $\mathrm{pH}$ studies were performed by shaking $25 \mathrm{~mL}$ of $20 \mathrm{mg} / \mathrm{L}$ of $\mathrm{Ca}$ (II) individual solution with $25 \mathrm{mg}$ of the adsorbent for $24 \mathrm{~h}$, to ensure the attainment of equilibrium over a wide range of initial $\mathrm{pH}$ values from 1.0 to 6.0. The samples were taken in $125 \mathrm{~mL}$ reagent bottles with an air-tight stopper. The equilibrium $\mathrm{pH}$ of the reaction mixture was recorded and the filtrate was used for the analysis of the remaining $\mathrm{Ca}$ (II) ion concentration. The experiments were conducted three times and the mean value was taken for the analysis of data. The optimum $\mathrm{pH}$ values were found out for the sorption of $\mathrm{Ca}$ (II) ions onto these adsorbents, which provides fruitful information for further study.

\section{Batch equilibrium time studies}

The equilibrium time of the adsorbents for the sorption of $\mathrm{Ca}(\mathrm{II})$ ion was investigated at optimum $\mathrm{pH}$ values at room temperature. $25 \mathrm{~mL}$ of $20 \mathrm{mg} / \mathrm{L}$ concentration of $\mathrm{Ca}$ (II) solutions were taken in 125 $\mathrm{mL}$ reagent bottle with $25 \mathrm{mg}$ adsorbents and was shaken in a mechanical shaker for $10 \mathrm{~min}, 20 \mathrm{~min}$, $30 \mathrm{~min}, 40 \mathrm{~min}, 50 \mathrm{~min}, 60 \mathrm{~min}, 70 \mathrm{~min}, 80 \mathrm{~min}, 90$ min, $100 \mathrm{~min}, 2 \mathrm{~h}, 4 \mathrm{~h}, 5 \mathrm{~h}, 6 \mathrm{~h}$, and 24 h, respectively. The metal ion concentration was determined by using ELICO SL 177 spectrophotometer.

\section{Batch kinetic studies}

The adsorption kinetic experiments were carried out at optimum $\mathrm{pH}$ for $\mathrm{Ca}(\mathrm{II})$ ion adsorption by equilibrating $25 \mathrm{mg}$ of adsorbents in $125 \mathrm{~mL}$ stopper bottles containing $25 \mathrm{~mL}$ of $20 \mathrm{mg} / \mathrm{L} \mathrm{Ca}$ (II) solution in each. Separate sets of various samples were kept on a mechanical shaker and shaken vigorously. Samples were filtered through filter paper and concentration before and after the adsorption was determined by the spectrophotometric method by analyzing the filtrate. The obtained data was tested with the pseudo-secondorder and second-order kinetic model [30].

\section{Effect of concentration of $\mathrm{Ca}$ (II) ions}

Adsorption isotherm studies were conducted by varying the initial concentration of $\mathrm{Ca}(\mathrm{II})$ ions from 10 to $500 \mathrm{mg} / \mathrm{L} .25 \mathrm{~mL}$ of different concentrations of $\mathrm{Ca}$ (II) solution were shaken by the mechanical shaker for $24 \mathrm{~h}$ with $25 \mathrm{mg}$ of adsorbent dose for both of the samples raw water hyacinth (RWH) and charred water hyacinth $(\mathrm{CWH})$. The remaining $\mathrm{Ca}(\mathrm{II})$ ion concentration was determined after filtering the reaction mixture by using a spectrophotometer individually. The experiment was repeated three times and the mean value was taken for analysis of data.

Effect of time on Ca(II)-EDTA complex formation To observe the effectiveness of EDTA solution, the absorbance was measured with the help of a spectrophotometer (UV-Vis spectrophotometer, ELICO SL 177) from 0-60 minutes at an interval of five minutes with $20 \mathrm{mg} / \mathrm{L}$ solutions at $\mathrm{pH} 1.5$.

From the metal concentration measured before and after adsorption $\left(c_{i}\right.$ and $c_{e}$, respectively) and dry weight of adsorbent (W), the concentration of Ca (II) ions adsorbed in $\mathrm{mg} / \mathrm{L}$ at equilibrium are computed by the formula,

$$
\mathrm{q}=\frac{\mathrm{c}_{\mathrm{i}}-\mathrm{c}_{\theta}}{\mathrm{w}} \times \mathrm{V}(\mathrm{mg} / \mathrm{g})
$$

where, $c_{i}$ and $c_{e}$ are the concentration of $\mathrm{Ca}(\mathrm{II})$ ions in $\mathrm{mg} / \mathrm{L}$ initially and at equilibrium respectively. $\mathrm{V}$ is the volume of the $\mathrm{Ca}$ (II) ions in the liter and $\mathrm{W}$ is the weight of adsorbent in gram.

Removal percentage is defined as the ratio of the decrease in metal ion concentration before and after adsorption to the initial concentration of metal in aqueous solutions.

$$
\begin{aligned}
& \text { So, Percentage amount }(A \%)=\frac{\mathrm{c}_{1}-\mathrm{c}_{e}}{\mathrm{c}_{e}} \times 100 \ldots \\
& \text { At equilibrium, } \mathrm{D}=\frac{\mathrm{q}_{e}}{\mathrm{c}_{\theta}}
\end{aligned}
$$

where 'A\%' is the adsorbed metal percentage from the solution and ' $\mathrm{D}$ ' is the distribution factor of the adsorption in $(\mathrm{L} / \mathrm{g})$.

\section{Results and Discussion}

The sorption of $\mathrm{Ca}$ (II) ions in an aqueous solution were examined by optimizing various physicochemical parameters such as $\mathrm{pH}$, adsorbate concentration, contact time, adsorbent dose. The absorbance of a blue-pink colored complex of $\mathrm{Ca}$ (II)-EDTA complex in $\mathrm{H}_{2} \mathrm{SO}_{4}$ solution at a maximum wavelength of 520 $\mathrm{nm}$, i.e., $\lambda_{\text {max }}$ is $520 \mathrm{~nm}$.

Effect of pH for adsorption of $\mathrm{Ca}$ (II) ion onto $\mathrm{CWH}$ The $\mathrm{pH}$ of the solution is the most important parameter in the removal of the metal ion by adsorption. The 
removal of $\mathrm{Ca}$ (II) ion was found to be decreased with increasing $\mathrm{pH}$. The maximum removal value was found to be 1.5 and this is an optimum $\mathrm{pH}$ for $\mathrm{CWH}$ as shown in Figure 1.

\section{Effect of time on Ca(II)-EDTA complex formation}

By measuring the absorbance at the interval of five minutes, it was found that the value of absorbance was decreasing slightly (Figure 2). It was seen that

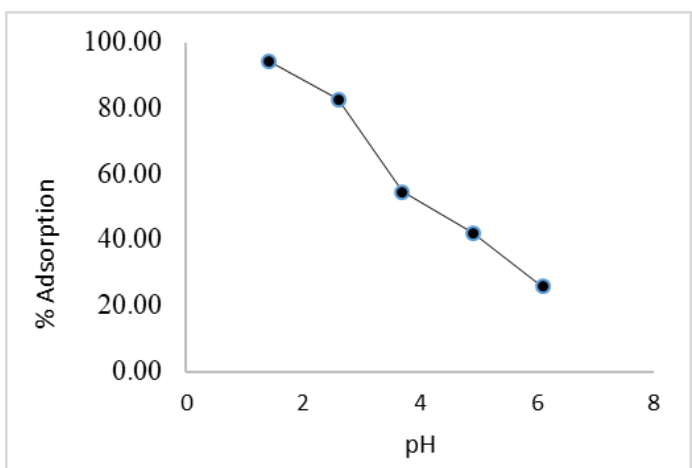

Figure 1: Effect of $p H$ on $\mathrm{Ca}(I I)$ ion adsorption by $\mathrm{CWH}$

from 0-20 minutes, the value of absorbance was found almost constant as shown in Figure 2. So, we measured the value of absorbance within 20 minutes by using EDTA solution.

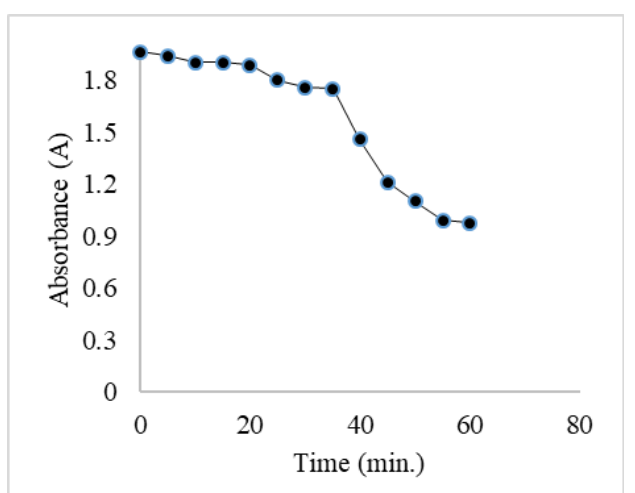

Figure 2: Effect of time on Ca(II) EDTA complex formation

Effect of contact time for adsorption of $\mathbf{C a}$ (II) ion onto CWH

Figure 3 depicts the study of adsorption which was carried out in measuring the effect of contact time on the batch adsorption of $50 \mathrm{mg} / \mathrm{L}$ metal solution with $25 \mathrm{mg}$ adsorbent for different time intervals ranging from 10 minutes to 360 minutes. The required time equilibrium for adsorption of $\mathrm{Ca}(\mathrm{II})$ ion onto $\mathrm{CWH}$ was found to be 250 minutes. The percentage of adsorption is gradually increased at the start and then remains almost constant after attaining a time equilibrium of 250 minutes due to the availability of a large surface area of adsorbent initially but later active sites of adsorbent get saturated [22].

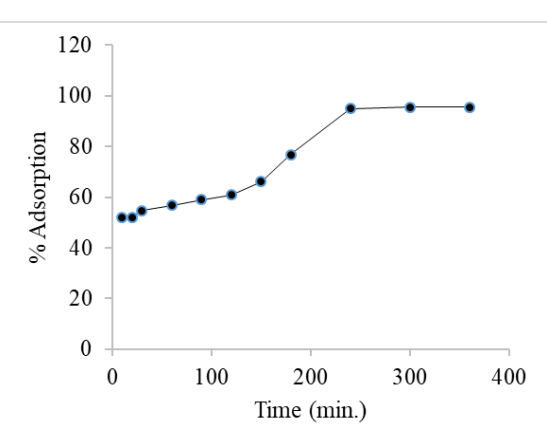

Figure 3: Effect of contact time for the adsorption percentage of $\mathrm{Ca}(\mathrm{II})$ ions onto $\mathrm{CWH}$

\section{Effect of $\mathrm{Ca}$ (II) ion concentration}

Figure 4 shows the effect of concentration in the adsorption of $\mathrm{Ca}(\mathrm{II})$ ions onto $\mathrm{CWH}$. The adsorption increases from a lower concentration to a higher concentration ranging from $5 \mathrm{mg} / \mathrm{L}$ to $200 \mathrm{mg} / \mathrm{L}$, the adsorbed amount increases from $43.2 \mathrm{mg} / \mathrm{g}$ to 319.75 $\mathrm{mg} / \mathrm{g}$. These data show that the adsorption is increased on increasing the amount of adsorbent.

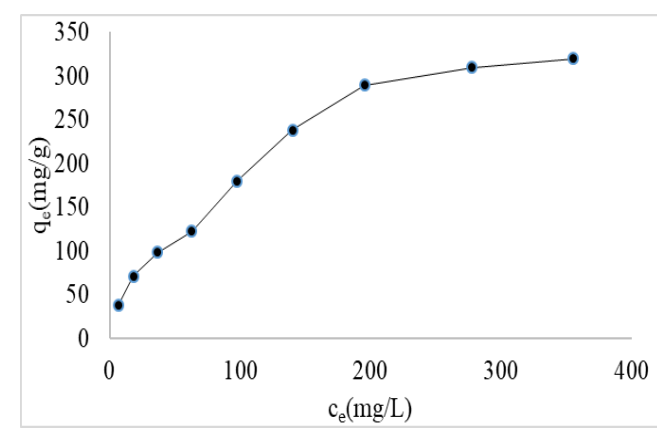

Figure 4: Effect of concentration in the adsorption of $\mathrm{Ca}(\mathrm{II})$ ions onto $\mathrm{CWH}$

\section{Batch isotherm studies}

Adsorption of $\mathrm{Ca}(\mathrm{II})$ ions onto $\mathrm{CWH}$ gives a linear relationship with Freundlich and Langmuir isotherms. Freundlich adsorption isotherm is more applicable due to having a greater correlation coefficient $\left(\mathrm{R}^{2}=0.98\right)$ than Langmuir adsorption isotherm $\left(\mathrm{R}^{2}=0.946\right)$. The Freundlich and Langmuir plots for the adsorption of $\mathrm{Ca}$ (II) ions onto $\mathrm{CWH}$ are shown in Figure 5 and Figure 6, respectively. The limited form of Freundlich isotherm is given by the following equation.

$$
\mathrm{q}_{\mathrm{c}}=\mathrm{Kc}_{\mathrm{e}}{ }^{1 / \mathrm{n}}
$$

In logarithmic form,

$$
\log \mathrm{q}_{\mathrm{c}}=\log \mathrm{K}+1 / \mathrm{n} \log \mathrm{c}_{\mathrm{e}}
$$

Where $q_{c}$ is the amount adsorbed per unit mass of adsorbent $(\mathrm{mg} / \mathrm{g}), \mathrm{c}_{\mathrm{e}}$ is the equilibrium concentration of the adsorbent $\mathrm{mg} / \mathrm{L}, \mathrm{K}$ and $\mathrm{n}$ are Freundlich equilibrium coefficients, which are considered to be relative indicators of adsorption capacity 
and adsorption intensity [24]. The better fitting of Freundlich model suggested the formation of multilayer coverage of $\mathrm{Ca}$ (II) ions on the surface of CWH.

\section{Batch kinetic studies}

The kinetic data for the adsorption of $\mathrm{Ca}$ (II) ion onto $\mathrm{CWH}$ was studied by using pseudo-second-order and second-order kinetics model. From these results, the pseudo-second-order model was found to be more suitable to describe adsorption kinetics than the second-order kinetics [20]. The pseudo-second-order kinetics is suitable for $\mathrm{Ca}$ (II) adsorption due to the higher value of $\mathrm{R}^{2}(0.99)$, indicating the adsorption is chemisorption. The plots of both second-order and pseudo-second-order models are shown in Figure 7 and Figure 8, respectively.

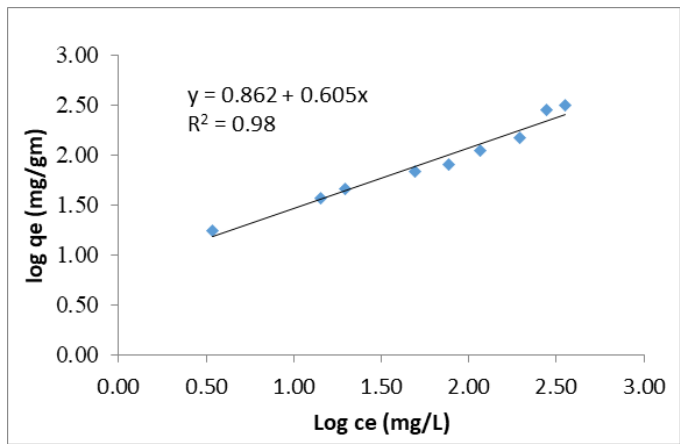

Figure 5: Freundlich isotherm plot for the adsorption of $\mathrm{Ca}(\mathrm{II})$ ion onto $\mathrm{CWH}$

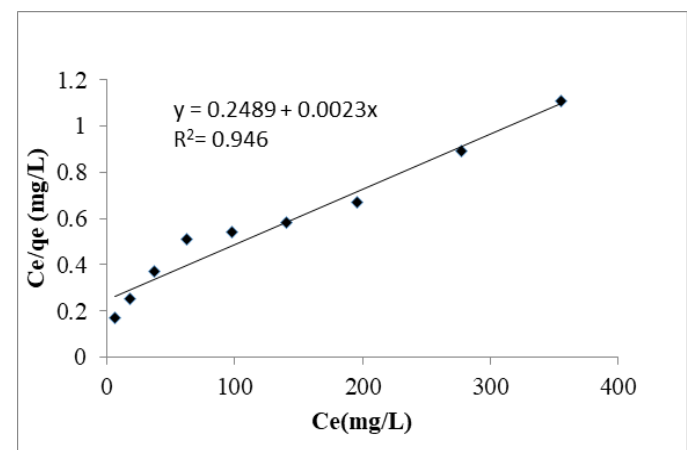

Figure 6: Langmuir isotherm plot for the adsorption of $\mathrm{Ca}(\mathrm{II})$ ion onto $\mathrm{CWH}$

\section{Determination of adsorption efficiency}

Determination of $\mathrm{Ca}(\mathrm{II})$ ion concentration was performed by EDTA titration. The adsorption efficiencies of activated carbon for each quantity of $\mathrm{Ca}(\mathrm{II})$ solution was calculated as follows:

Efficiency $=$ (initial concentration - collected concentration) $\times 100 /$ initial concentration..... (vi)

The graph of adsorption efficiencies and collected volumes of $\mathrm{Ca}$ (II) ion solution is plotted in Figure 9.

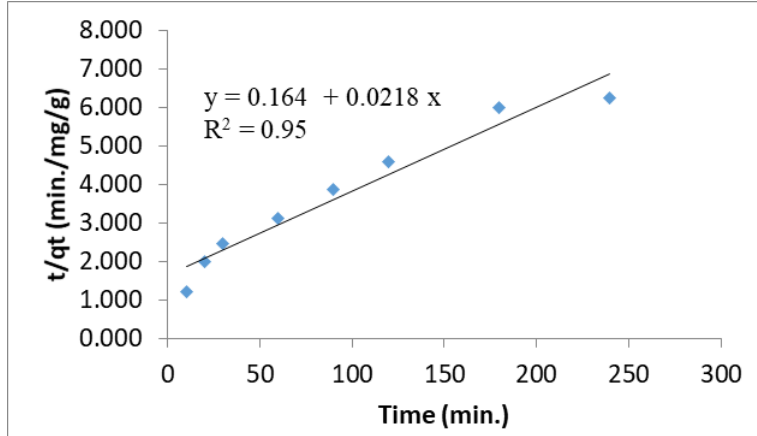

Figure 7: Second order kinetic plot for the adsorption of $\mathrm{Ca}^{2+}$ ion onto $\mathrm{CWH}$

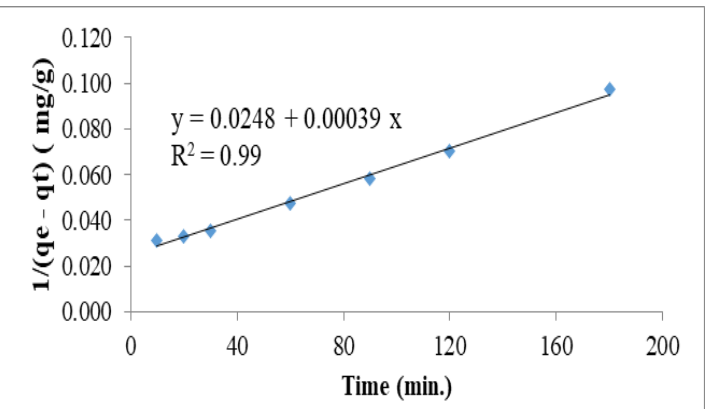

Figure 8: Pseudo-second order kinetic plot for the adsorption of $\mathrm{Ca}(\mathrm{II})$ ion onto $\mathrm{CWH}$

It was found that the highest adsorption efficiency of activated carbon for $\mathrm{Ca}(\mathrm{II})$ ion was about $91.8 \%$.

The comparison of the isotherm and kinetic parameters for different metal ions using $\mathrm{CWH}$ as adsorbent is mentioned in Table 1.

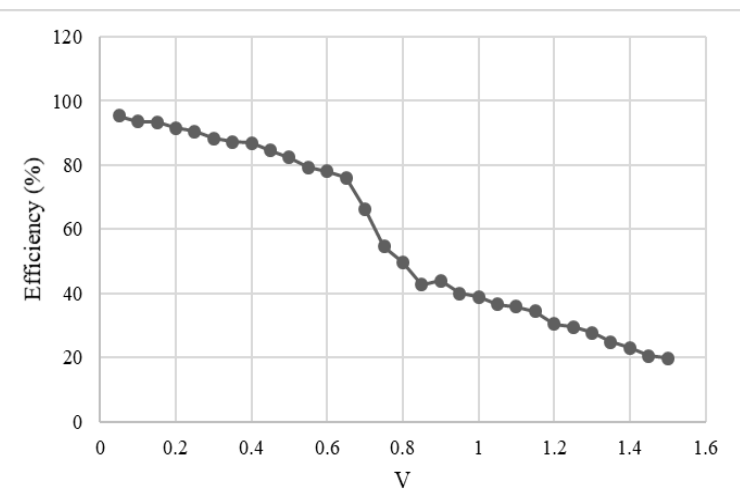

Figure 9: Efficiency of the column (in \%) concerning the volumes of the collected solution of Ca(II) (in L)

\section{SEM and EDX studies}

SEM image and EDX spectra (JEOL JSM - 6700F) were carried out to study the morphology and elemental composition of the adsorbent. Figure 10 depicts the SEM micrograph of charred water hyacinth.

The irregular and very rough surfaces could be observed in chemically modified water hyacinth 
Table 1: Comparison of isotherm and kinetic parameters for different metal ions

\begin{tabular}{|c|c|c|c|c|c|c|}
\hline $\begin{array}{l}\text { Metal ions } \\
\text { using CWH }\end{array}$ & Isotherm & Kinetics & $\mathrm{Q}_{\max }(\mathrm{mg} / \mathrm{g})$ & pH & Efficiency (\%) & References \\
\hline $\mathrm{Zn}(\mathrm{II})$ & Langmuir & Pseudo $2^{\text {nd }}$ order & & 6 & 79.6 & [32] \\
\hline $\mathrm{Cu}(\mathrm{II})$ & Langmuir & Pseudo $2^{\text {nd }}$ order & & 6 & 92 & [32] \\
\hline $\mathrm{Cr}(\mathrm{VI})$ & Langmuir & Pseudo $2^{\text {nd }}$ order & 101.01 & 2 & & [33] \\
\hline $\mathrm{Cd}(\mathrm{II})$ & Langmuir & Pseudo $2^{\text {nd }}$ order & 104.16 & 6 & 70 & [19] \\
\hline $\mathrm{Ca}$ (II) & Freundlich & Pseudo $2^{\text {nd }}$ order & 319.75 & 1.5 & 91.8 & This study \\
\hline
\end{tabular}

which confirms that the hydrolysis reaction occurs on the surface of water hyacinth by the action of acidified $\mathrm{ZnCl}_{2}$ solution. The irregular and rough surfaces were developed by $\mathrm{ZnCl}_{2}$ due to the cleavage of polymeric networks of water hyacinth and converted it into small particles with large volume or surface area.

Figures 11(a) and 11(b) show the EDX spectra of adsorbent before and after $\mathrm{Ca}(\mathrm{II})$ ion adsorption, respectively. The presence of a peak for calcium ion is seen in EDX spectra only after adsorption, which confirms the good adsorption of calcium.

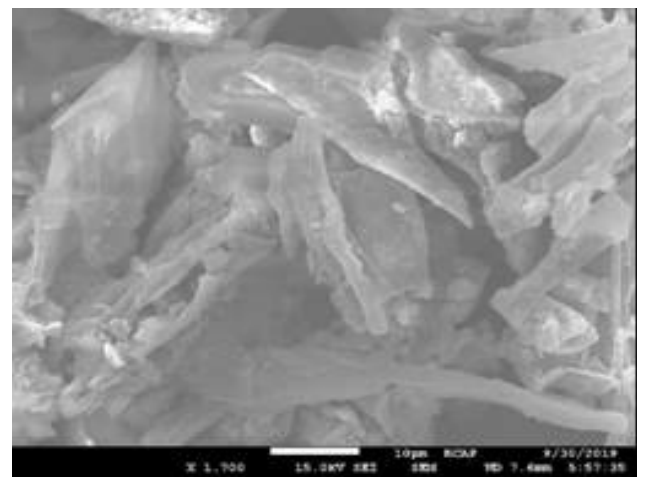

Figure 10: SEM micrograph of charred water hyacinth

Table 2(a): Elemental composition of CWH before Ca(II) ion adsorption

\begin{tabular}{lll}
\hline Elements & Weight \% & Atomic \% \\
\hline C K & 45.66 & 57.29 \\
O K & 37.28 & 35.21 \\
Al K & 1.06 & 0.59 \\
Si K & 12.36 & 6.63 \\
Pt K & 3.64 & 0.28 \\
\hline Total & $\mathbf{1 0 0 . 0 0}$ & $\mathbf{1 0 0}$ \\
\hline
\end{tabular}

Table 2(b): Elemental composition of $\mathrm{CWH}$ after $\mathrm{Ca}(\mathrm{II})$ ion adsorption

\begin{tabular}{ccc}
\hline Elements & Weight \% & Atomic \% \\
\hline C K & 61.17 & 69.14 \\
O K & 30.19 & 26.36 \\
Al K & 1.02 & 0.53 \\
Si K & 1.38 & 0.40 \\
Ca K & 2.93 & 1.69 \\
Pt L & 1.52 & 0.88 \\
\hline Total & 100.00 & 100 \\
\hline
\end{tabular}

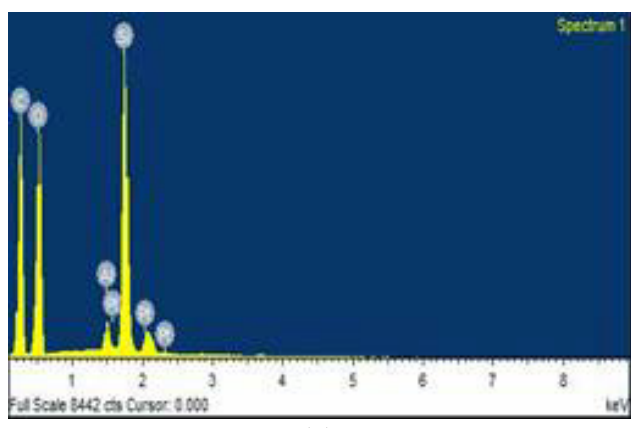

(a)

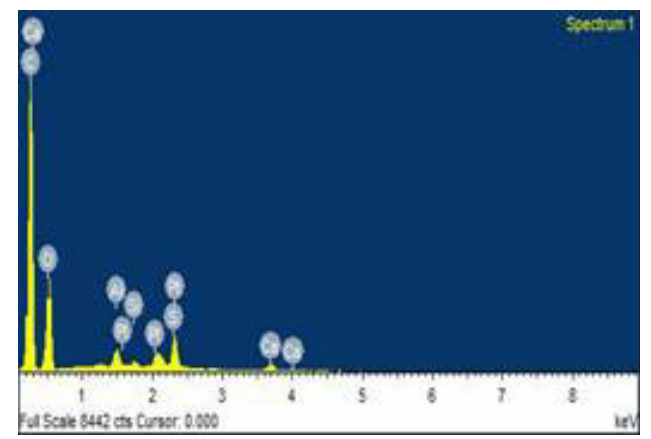

(b)

Figure 11: EDX spectra of adsorbent (a) before and (b) after $\mathrm{Ca}(I I)$ ion adsorption

Table 2(a) and Table 2(b) depict the elemental composition of $\mathrm{CWH}$ before and after $\mathrm{Ca}(\mathrm{II})$ ion adsorption, respectively obtained from EDX analysis. As given in Table 2(a), only main elements $(\mathrm{C}$ and $\mathrm{O}$ ) along with some other elements ( $\mathrm{Al}, \mathrm{Si}$, and $\mathrm{Pt}$ ) are observed, but the presence of $\mathrm{Ca}$ (II) ion as shown in Table 2(b) suggests that it is successfully adsorbed by $\mathrm{CWH}$.

\section{Conclusion}

The low-cost adsorbent, water hyacinth, can be used as a new type of adsorbent for the removal of $\mathrm{Ca}(\mathrm{II})$ ions by the adsorption process. The optimum $\mathrm{pH}$ for the adsorption of $\mathrm{Ca}(\mathrm{II})$ ions is 1.5 and the Freundlich adsorption isotherm model with correlation coefficient $\mathrm{R}^{2}$ of 0.98 was more applicable than the Langmuir isotherm model $\left(\mathrm{R}^{2}=0.946\right)$. The maximum adsorption capacity of $\mathrm{Ca}(\mathrm{II})$ ions onto $\mathrm{CWH}$ is found 
to be $319.75 \mathrm{mg} / \mathrm{g}$. The required time equilibrium for the adsorption of $\mathrm{Ca}(\mathrm{II})$ ions onto $\mathrm{CWH}$ was found to be 250 minutes. The experimental data were better described by the pseudo-second-order kinetics model. The adsorbed concentration of $\mathrm{Ca}$ (II) ion was calculated by EDTA titration and efficiency was found to be $91.8 \%$. Due to the presence of a rough surface, verified from the SEM image, charred water hyacinth has greater efficiency of the adsorption capacity. The EDX spectra indicate the successful adsorption of the $\mathrm{Ca}(\mathrm{II})$ ions.

\section{Acknowledgments}

The authors are thankful to the Department of Chemistry, Tri-Chandra Campus, Tribhuvan University for providing lab facilities and necessary materials. Thanks are due to Jawaharlal Nehru Centre for Advanced Scientific Research (JNCASR), Bangalore (India) for SEM and EDX measurements.

\section{References}

1. D. Perrone and M. Monteiro, The chemistry of calcium, Food and Nutritional Components in Focus, 2016, 10, 67-74. (DOI: 10.1039/9781782622310-00067)

2. P. Pravina, D. Sayaji, and M. Avinash, Calcium and its role in the human body, International Journal of Research in Pharmaceutical and Biomedical Sciences, 2013, 4(2), 659-668.

3. S. Panumati, K. Chudecha, P. Vankhaew, V. Choolert, L. Chuenchom, W. Innajitara and O. Sirichote, Adsorption efficiencies of calcium (II) ion and iron (II) ion on activated carbon obtained from the pericarp of rubber fruit, Songklanakarin, Journal of Science and Technology, 2008, 30(2), 179-183.

4. K. Li, X. F. Wang, D. Y. Li, Y. C. Chen, L. J. Zhao, Xiao. G. Liu, Y. F. Guo, J. Shen, X. Lin, J. Deng, R. Zhou and H. W. Deng, The good, the bad, and the ugly of calcium supplementation: a review of calcium intake on human health, Clinical Interventions in Aging, 2018, 13, 2443-2452.

5. P. Sengupta, Potential health impacts of hard water, International Journal of Preventive Medicine, 2013, 4(8).

6. A. Y. D. Lestari, A. Malik, Sukirman, M. I. Ilmi, and M. Sidiq, Removal of calcium and magnesium ions from hard water using modified Amorphophallus campanulauts skin as a lowcost adsorbent, MATEC Web of Conference 2018, 154, 1-4. (DOI: https://doi.org/10.1051/ matecconf/201815401020)

7. S. E. Cahyaningrum, Narsito, S. J. Santoso and R. Agustini, Capacity and kinetic adsorption of calcium metal ion on chitosan nanobeads, Research Journal of Pharmaceutical, Biological and Chemical Sciences, 2016, 7(3), 1764-1767.

8. P. E. Franco, M. T. Veit, C. E. Borba, da Cunha Goncalves, G, M. Fagundes-Klen MR, and PYR Suzaki, Nickel (II) and zinc (II) removal using Amberlite IR-120 resin: Ion exchange equilibrium and kinetics, Chemical Engineering Journal, 2013, 221, 426-435. (DOI: https://doi. org/10.1016/j.cej.2013.02.006)

9. S. Mohan and R. Gandhimathi, Removal of heavy metal ions from municipal solid waste leachate using coal fly as an adsorbent, Journal of Hazardous Materials, 2009, 169(1-3), 351-359. (DOI: https:// doi.org/10.1016/j.jhazmat.2009.03.104)

10. E. P. Barret, L.G. Joyner, and P. H. Halenda, The determination of pore volume and area distribution in porous substances. I. Computation from nitrogen isotherms, Journal of American Chemical Society, 1951, 73, 373-380.

11. J. U. Okoli, and I. Ezuma, Adsorption studies of heavy metals by low-cost adsorbents, Journal of Applied Sciences and Environment Management, 2014, 18(3), 443-448. (DOI: http://doi. org/10.4314/jasem.v18i3.11)

12. H. Panda, N. Tiadi, M. Mohanty and C. R. Mohanty, Studies on adsorption behavior of an industrial waste for removal of chromium from aqueous solution, South African Journal of Chemical Engineering, 2017, 23, 132-138. (DOI: https://doi.org/10.1016/j.sajce.2017.05.002)

13. M. S. Gawande, A. A. Mane, and N. S. Belwalker, Experimental study of activated carbon derived from dried water hyacinth and its performance in phosphate removal from wastewater, International Journal of Current Research, 2017, 9(7), 5351453517.

14. S. P. Dubey, and K. Gopal, Adsorption of Chromium (VI) on low-cost adsorbents derived from agricultural waste material, Journal of Hazardous Materials, 2007, 145(3), 456-470.

15. A. Shrestha, B. R. Poudel, M. Silwal, and M. R. Pokhrel, Adsorptive removal of phosphate onto Iron loaded Litchi chinesis seed waste, Journal of Institute of Science and Technology, 2018, 23, 81-87. (DOI: https://doi.org/10.3126/jist. v23i1.22200)

16. R. L. Aryal, B. R. Poudel, S. K. Gautam, H. Paudyal, M. R. Pokhrel, and K. N. Ghimire, Removal of fluoride from aqueous solution using biomass-based adsorbent: A review, Journal of Nepal Chemical Society, 2019, 40, 44-51. (DOI: https://doi.org:10.3126/jncs.v40i0.27281) 
17. M. R. Pokhrel, B. R. Poudel, R. L. Aryal, H. Paudyal, and K. N. Ghimire, Removal and recovery of phosphate from water and wastewater using metal-loaded agricultural waste-based adsorbents: a review, Journal of Institute of Science and Technology, 2019, 24(1), 77-89. (DOI: https://doi.org/10.3126/jist.v24i1.24640)

18. U. Khatri, R. B. Thapa, and U. Paudel, Willingness to pay for Water Hyacinth control in Nepal, American Journal of Environmental Science, 2018, 14(5), 226-233. (DOI: 10.3844/ ajessp.2018.226.233)

19. G. Murithi, C. O. Onindo, E. W. Wambu, and G. K. Muthakia, Removal of Cadmium (II) ions from water by adsorption using water hyacinth (Eichhornia crasssipes) biomass, Bioresources, 2014, 9(2), 3613-3631.

20. C. Mahamadi and T. Nharingo, Utilization of water hyacinth weed (Eichhornia crassipes) for the removal of $\mathrm{Pb}(\mathrm{II}), \mathrm{Cd}(\mathrm{II})$ and $\mathrm{Zn}(\mathrm{II})$ from aquatic environments: an adsorption isotherm study, Environmental Technology, 2010, 31(11), 1221-1228. (DOI: https://doi. org/10.1080/09593331003646604)

21. P. R. Bhatt, R. L. Aryal, B. R. Poudel, S. Bhattarai and S. K. Gautam, Adsorptive removal of $\mathrm{Cr}$ (VI) from aqueous solution onto charred sugar cane bagasse, Journal of Nepal Chemical Society, 2018, 39, 62-69. (DOI: https://doi.org/10.3126/ jncs.v39i0.27035)

22. D. L. Adhikari, R. L. Aryal, S. Bhattarai, S. K. Gautam, and B. R. Poudel, Removal of chromium (VI) from aqueous solution using chemically modified sweet lime (Citrus limetta) peels as adsorbent, Journal Nepal Chemical Society, 2017, 36, 82-95.

23. S. Karki, R. L. Aryal, S. Bhattrai, S. K. Gautam, and B. R. Poudel, Adsorptive removal of arsenic (III) from aqueous solution using chemically modified sweet lime (Citrus limette) peel, Journal of Nepal Chemical Society, 2017, 37, 11-19.

24. S. Thapa and M. R. Pokhrel, Removal of As(III) from aqueous solution using $\mathrm{Fe}$ (III) loaded pomegranate waste, Journal of Nepal Chemical Society, 2012, 30, 29-36. (DOI: https://doi.org/10.3126/jncs.v30i0.9332)

25. B. R. Poudel, R. L. Aryal, S. Bhattarai, A. R. Koirala, S. K. Gautam, K. N. Ghimire, B. Pant, M. Park, H. Paudyal and M. R. Pokhrel, Agrowaste derived biomass impregnated with $\mathrm{TiO}_{2}$ as a potential adsorbent for removal of $\mathrm{As}(\mathrm{III})^{2}$ from water, Catalysts, 2020, 10(10), 1125. (DOI: https://doi.org/10.3390/catal10101125).
26. B. R. Poudel, R. L. Aryal, L. B. Khadka, K. N. Ghimire, H. Paudyal, and M. R. Pokhrel, Development of biomass-based anion exchanger for the removal of trace concentration of phosphate from Water. Journal of Nepal Chemical Society, 2020, 41, 56-63. (DOI: https://doi. org/10.3126/jncs.v41i1.30488)

27. A. Malik, Environmental challenge and its opportunity: The case of water hyacinth, Environment International, 2007, 33, 122-138. (DOI: https://doi.org/10.1016/j. envint.2006.08.004)

28. E. Akyol and M. Oner, Controlling of morphology and polymorph of Calcium Oxalate crystal by using polyelectrolytes, Journal of Crystal Growth, 2014, 401, 260-265.(DOI: https://doi. org/10.1016/j.jcrysgro.2013.12.028)

29. K. Kadirvelu and C. Namasivayam, Activated carbon from coconut coir pith as metal adsorbent: Adsorption of $\mathrm{Cd}(\mathrm{II})$ from aqueous solutions, Advances in Environmental Research, 2003, 7, 471-478.

30. N. N. Bandela, M. G. Babrekar, O. K. Jogdand, and G. Kaushik, Removal of copper from aqueous solution using local agricultural wastes as low-cost adsorbent, Journal of Materials and Environmental Science, 2016, 7(6),1972-1978.

31. G. H. Pino, L. M. S. de Mesquita, M. L. Torem and G. A. S. Pinto, Biosorption of heavy metals by a powder of green coconut shell, Separation Science and Technology, 2006, 41, (DOI: https:// doi.org/10.1080/01496390600851640)

32. B. C. Nyamunda, T. Chivhanga, U. Guyo, and F. Chigondo, Removal of $\mathrm{Zn}(\mathrm{II})$ and $\mathrm{Cu}(\mathrm{II})$ ions from industrial wastewaters using magnetic biochar derived from water hyacinth, Journal of Engineering, 2019, 2019, 1-11. (DOI: https://doi. org/10.1155/2019/5656983)

33. S. H. Hasan, D. Ranjan, and M. Talat, Water hyacinth biomass (WHB) for the biosorption of hexavalent chromium: optimization of process parameters, Bioresources, 2010, 5(2), 563575. 